\title{
ANALYSIS OF FOREIGN TRADE IN SELECTED MANUFACTURING INDUSTRY COMMODITIES
}

\author{
Petra MARTINKOVÁ, Kamila JANOVSKÁ, Šárka VILAMOVÁ, Marek ŠAFRÁNEK, \\ Iveta VOZŇÁKOVÁ \\ VSB - Technical University of Ostrava, Faculty of Materials Science and Technology, Ostrava, \\ Czech Republic, EU, petra.martinkova@vsb.cz, kamila.janovska@vsb.cz, sarka.vilamova@vsb.cz, \\ marek.safranek.st@vsb.cz, iveta.voznakova@vsb.cz
}

https://doi.org/10.37904/metal.2021.4289

\begin{abstract}
Export oriented companies are extremely important for the Czech Republic as a highly open economy. These companies contribute to the generation of GDP and ensure that the current account on its balance of payments remains balanced. International trade is currently enjoying rapid growth because most trading subjects are aware of the importance of developing international activities which aim to sell products on foreign markets. This high sectoral concentration of Czech exporters along with a significant territorial export orientation primarily towards EU states means the Czech Republic is highly vulnerable to fluctuations and economic disturbances on foreign markets. The research investigates application of the gravity model of foreign trade on selected branches of the manufacturing industry and identifies significant factors which affect trade flow. The main aim of the research was to determine statistically significant export variables and generally confirm the suitability of using the gravity model equation as a tool for analysing trade flow and discovering trade potential. Part of the research involved compiling a basic modified export gravity model of foreign trade. This model allows identification of the statistically significant explanatory variables which fundamentally affect the Czech Republic's exports. The paper presents this model and the outputs which relate to selected commodities produced by the manufacturing industry, such as basic metals, coke and oil products, chemical substances and preparations, etc.
\end{abstract}

Keywords: Analysis, export, foreign trade, gravity model

\section{INTRODUCTION}

Foreign trade represents a significant constituent of external economic relations because it links the national economy with the global economy. The research investigated application of the gravity model of foreign trade on selected branches of the manufacturing industry and identified significant factors which affect the trade flow in selected commodities. Part of the research involved compilation of a basic modified export gravity model. "Exports from the Czech Republic" was selected as an explanatory variable, along with "GDP", "GDP per Capita", "distance of trade partners", and "population size" of 35 selected countries which represent the main business partners of the Czech Republic. All the estimates of the variables' parameters were made using the GRETL program. Tests were applied to ascertain the stationarity of the variables in the panel data and the relationship between the analysed variables. The paper presents a modified export gravity model of foreign trade. The model allows identification of the statistically significant explanatory variables which fundamentally affect the Czech Republic's exports. Selected commodities such as basic metals, coke and oil products, chemical substances and preparations produced by the manufacturing industry were examined (see Tables $1,2$ and 3$)$. 
Table 1 Export of goods from the Czech Republic of selected commodities produced by the manufacturing industry [in billions CZK] for the selected period [1]

\begin{tabular}{|c|c|c|c|c|c|c|}
\hline Commodity & 1.y & 2.y & 3.y & 4.y & 5.y & 6.y \\
\hline Coke and refined oil products & 39.0 & 37.2 & 42.2 & 38.3 & 28.4 & 36.6 \\
\hline Chemical substances and preparations & 146.5 & 152.1 & 166.9 & 150.3 & 140.8 & 160.5 \\
\hline Basic metals & 149.3 & 150.9 & 151.5 & 142.0 & 128.9 & 138.7 \\
\hline
\end{tabular}

Table 2 Year-on-year development of selected commodities produced by the manufacturing industry during the monitored period [\%] [1]

\begin{tabular}{|c|c|c|c|c|c|}
\hline Commodity & $\mathbf{1 . y}$ & $\mathbf{2 . y}$ & $\mathbf{3 . y}$ & $\mathbf{4 . y}$ & $\mathbf{5 . y}$ \\
\hline Coke and refined oil products & -5 & 13 & -9 & -26 & 29 \\
\hline Chemical substances and preparations & 4 & 10 & -10 & -6 & 14 \\
\hline Basic metals & 1 & 0 & -6 & -9 & 8 \\
\hline
\end{tabular}

Table 3 Foreign trade in goods in 2017 in the Czech Republic [in billions of CZK] of selected commodities produced by the manufacturing industry [1]

\begin{tabular}{|c|c|c|c|c|}
\hline Commodity & Trade turnover & Export & Import & Trade balance \\
\hline Coke and refined oil products & 89.922 & 36.551 & 53.371 & -16.819 \\
\hline Chemical substances and preparations & 430.450 & 160.497 & 269.953 & -109.456 \\
\hline Basic metals & 403.309 & 138.722 & 264.586 & -125.864 \\
\hline
\end{tabular}

In the 1960s, Tinberger and Pöyhönen first presented the gravity model of foreign trade $[2,3]$. According to the authors, the mutual volume of trade between countries could be likened to the law of gravitational attraction in Newtonian physics: it was directly dependent on the size of the countries or the size of their economic power expressed in GDP and inversely proportional to the geographic distance between them, most often expressed as the distance between capitals. Gravity models have long been used to analyse the effect of globalisation factors on bilateral trade [4]. Gravity models can be used to explain international financial transactions in the same manner as transactions in goods [5] and can also be applied in the international trade network [6]. Baier and Bergstrand conducted extensive research into the application of gravity models and also formulated the most commonly used gravity model in international trade [7-9].

As the number of application areas for gravity models grows, the number of potential explanatory variables which can be modelled under the relevant phenomena also grows. One can select a concrete explanatory variable from a large number of characteristics. According to Bubáková, in the traditional concept of the gravity model, the volume of mutual trade is dependent on the economic strength of the country, transport costs, trade barriers and preferential factors [10]. Mutual trade is then represented by trade flow. In a study of the agricultural commodities produced by the Czech Republic, Ševela formulated a gravity model for Czech exports, with GDP, GDP per capita, and geographic distance between capitals as the statistically significant explanatory variables [11]. Svatoš and Smutka evaluated the competitiveness of Czech agricultural and food products in the context of the global agrarian market and agrarian foreign trade of the $27 \mathrm{EU}$ Member States [12]. Tichý applied the gravity model to produce an estimate of the impact of the Czech Republic's accession to the European Monetary Union on foreign trade in the Czech Republic [13]. Benáček, Podpiera and Prokop (2005) showed that for almost a decade (1993-2002), the most important factors which affected trade between the Czech Republic and the EU were aggregate demand on both sides of the border, the real exchange rate, liberalisation of customs and unit prices in imports and exports, and economies of scale [14]. In areas associated with trade, some studies examined the backing given to companies to support competitiveness in the Czech Republic $[15,16]$. Several Czech authors have investigated the factors which affect export 
competitiveness. Peprný, Kubíčková and Rovný defined the indicators for the success of SMEs on foreign markets [17].

\section{RESEARCH OBJECTIVE AND METHODOLOGY}

\subsection{Basic gravity model}

The research applied panel data compiled from statistics available from Eurostat, the Czech Statistical Office, the Foreign Trade Database of the Czech Republic, the Czech National Bank, and the European Central Bank. The research assembled a basic gravity model which contains explanatory variables selected according to an analysis of macroeconomic factors. The statistical model was then dynamized, and a gravity model was put together with basic and secondary explanatory variables. Exports in the Czech Republic was selected as an explanatory variable. To analyse the main factors which affect Czech exports, panel data was assembled, consisting of cross-sectional data which monitored a five-year period of the 35 most significant territories for the export of Czech products. GDP, GDP per capita, and geographic distance between capitals were then applied in the model as statistically significant explanatory variables.

After substitution of the defined variables, the basic equation is expressed in Equation 1.

$X_{i j t}=\alpha_{0}+\alpha_{1} G D P_{i t}+\alpha_{2} G D P_{j t}+\alpha_{3} P O P_{i t}+\alpha_{4} P O P_{j t}+\alpha_{5} D I S T_{i j}+\alpha_{6} G D P C A P_{i t}+\alpha_{7} G D P C A P_{j t}+\varepsilon_{i j t}$

\subsection{Modified gravity model}

Based on economic, statistical and econometric verification, the gravity model described in (1) was modified into a form for determining the main factors involved in the Czech Republic's foreign trade [18]. The modified gravity model is expressed in Equation 2.

$\ln \left(X_{i j t}\right)=\alpha_{0}+\alpha_{1} \ln \left(G D P_{i t}\right)+\alpha_{2} \ln \left(G D P_{j t}\right)+\alpha_{3} \ln \left(P O P_{i t}\right)+\alpha_{4} \ln \left(P O P_{j t}\right)+\alpha_{5} \ln \left(D I S T_{i j}\right)+$ $\alpha_{6} \ln \left(G D P C A P_{i t}\right)+\alpha_{7} \ln \left(G D P C A P_{j t}\right)+\varepsilon_{i j t}$

where:

$X_{i j t} \quad$ value of export from country $i$ (Czech Republic) to country $j$

$G D P_{i t} \quad$ gross domestic product of country $i$ (Czech Republic)

$G D P_{j t} \quad$ gross domestic product of country $j$ (partner country)

GDPCAP $_{i t} \quad$ gross domestic product of country $i$ (Czech Republic) per capita

$G_{P P C A P} \mathrm{t} \quad$ gross domestic product of country $j$ (partner country) per capita

$P O P_{i t} \quad$ population of country $i$ (Czech Republic)

$P O P_{j t} \quad$ population of country $j$ (partner country)

$D_{S I S T} \quad$ geographic distance between countries $i$ (Czech Republic) and $j$ (partner country)

$\varepsilon_{i j t} \quad$ random error

\section{RESULT AND DISCUSSION}

All the estimates of the variables' parameters were made using the GRETL program. The model included a variable for time. The assumption concerning a statistically significant year was not confirmed. The least squares model was applied to Czech exports according to a Hausman test, which detects the consistency of estimates, with a resultant $p$-value of 0.34562 [19]. Table 4 lists the values of the coefficients for individual variables in the resultant model of random effects along with $p$-values which indicate the statistical significance of the individual explanatory variables. The dependent variable is "In Export". 
Table 4 Estimate of variables in model

\begin{tabular}{|c|c|c|c|}
\hline Variable & Coefficient $\alpha$ & Standard error & p-value \\
\hline const & 4.57824 & 0.830202 & $1.27 \mathrm{e}-07$ \\
\hline I_GDP ${ }_{\mathrm{jt}}$ & 0.809565 & 0.0311539 & 0.4323 \\
\hline I_GDPCAP $\mathrm{jt}_{\mathrm{f}}$ & -0.234374 & 0.0474901 & $1.89 \mathrm{e}-06$ \\
\hline I_POP $_{\mathrm{jt}}$ & 0.2563 & 0.034645 & $1.49 \mathrm{e}-07$ \\
\hline I_DIST & -1.35654 & 0.0460095 & 0.6471 \\
\hline I_GDP & 0.448752 & 0.778176 & $1.76 \mathrm{e}-046$ \\
\hline I_GDPCAP & 0.2097 & 0.056435 & $1.24 \mathrm{e}-06$ \\
\hline
\end{tabular}

The analysis showed that the basic macroeconomic theory of foreign trade can also be applied to trade in the Czech Republic. The result of the analysis is a positive value of GDP, corresponding to the expectation that countries export more to other countries with a higher GDP. From the aspect of intensity of effect, the most powerful factor on the volume of exports is distance between countries. In accordance with the theory of gravity models, the volume of goods traded between business partners drops with increasing distance. The greater the GDP and the less the distance from the Czech Republic, the higher the exports to that country. The other parameters showed no statistical significance.

The obtained coefficient values were applied to the gravity model, results are displayed in Equation 3.

$$
\begin{aligned}
& \ln \left(X_{i j t}\right)=4.57824+0.809565 \ln \left(G D P_{j t}\right)+0.448752 \ln \left(G D P_{i t}\right)+0.2563 \ln \left(P O P_{i t}\right)+0.2678 \ln \left(P O P_{j t}\right)- \\
& 1.35654 \ln \left(D I S T_{i j}\right)-0.234374 \ln \left(G D P C A P_{j t}\right)+0.2097 \ln \left(G D P C A P_{i t}\right)
\end{aligned}
$$

In the analysis, a revealed comparative advantages (RCA) index was also calculated and used to evaluate the comparative advantages of the examined country with respect to the reference group, according to the equation [20], see Equation 4.

$R C A_{i j}=\frac{\left(\frac{x_{i j}}{x_{i}}\right)}{\left(\frac{x_{w j}}{x_{w}}\right)}$

where:

$x_{i j} \quad$ value of export of the given commodity by a certain country

$X_{i} \quad$ value of total exports of a certain country to the entire world

$x_{w j} \quad$ value of global exports of the examined commodity $1,000=$ one thousand

$X_{w} \quad$ total value of global exports

If the resultant value is greater than 1 , then the examined country has a comparative advantage in terms of the reference group of countries in exports of the given commodity category. Table $\mathbf{5}$ shows that with its trade partners in selected countries, the Czech Republic has a full comparative advantage in the category of machines and vehicles, whereas in chemical substances and preparations and coke and oil products, the Czech Republic has full comparative disadvantages with all countries. In the case of basic metals, the Czech Republic has a comparative advantage only with directly neighbouring countries. 
Table 5 RCA index of selected commodities for 2017

\begin{tabular}{|c|c|c|c|c|}
\hline & $\begin{array}{c}\text { Machinery and } \\
\text { vehicles }\end{array}$ & $\begin{array}{c}\text { Chemical substances and } \\
\text { preparations }\end{array}$ & $\begin{array}{c}\text { Basic } \\
\text { metals }\end{array}$ & $\begin{array}{c}\text { Coke and refined oil } \\
\text { products }\end{array}$ \\
\hline Germany & 1.55 & 0.33 & 1.33 & 0.17 \\
\hline Slovakia & 1.03 & 0.69 & 1.59 & 0.89 \\
\hline Poland & 1.09 & 0.92 & 2.03 & 0.42 \\
\hline France & 1.80 & 0.26 & 0.84 & 0.04 \\
\hline UK & 1.82 & 0.23 & 0.85 & 0.03 \\
\hline Austria & 1.13 & 0.37 & 1.51 & 0.00 \\
\hline Italy & 1.33 & 0.53 & 1.37 & 0.01 \\
\hline Netherlands & 1.69 & 0.36 & 1.33 & 0.06 \\
\hline Hungary & 1.41 & 0.89 & 0.64 & 0.40 \\
\hline Spain & 1.99 & 0.24 & & 0.00 \\
\hline
\end{tabular}

\section{CONCLUSION}

The article presented the outputs of an analysis in which the main aim was to determine the statistically significant export variables related to the selected commodities produced by the manufacturing industry: basic metals, coke and oil products, chemical substances and preparations. As part of the research, a modified form of the gravity model was compiled, and the revealed comparative advantages index was calculated. The research analysed the significance of individual factors comprising the actual export policy and determined the most significant aspects in the Czech environment, evaluating how they affected competitiveness on the foreign market in selected manufacturing industry commodities such as basic metals, coke and oil products and chemical substances and preparations. According to the model, export success is in general dependent primarily on the economic growth of the country (GDP indicator) and the distance between the trading partners.

\section{ACKNOWLEDGEMENTS}

\section{The work was supported by the specific university research of the Ministry of Education, Youth and} Sports of the Czech Republic in VSB - Technical University of Ostrava No. SP2021/43.

\section{REFERENCES}

[1] Český statistický úřad. [online], [viewed: 2021-03-24]. Available from: https://www.czso.cz/

[2] TIMBERGEN, J. Shaping the World Economy: Suggestions for an International Economic Policy. [online]. New York: The Twentieth Century Fund, 1962. Available from: https://doi.org/10.2307/1236502.

[3] PÖYHÖNEN, P. A Tentative Model for the Volume of Trade Between Countries'. Weltwirtchaftliches Archiv, 1963. vol. 90, pp. 93-100.

[4] BERGRSTRAND, J. H., EGGER, P. Gravity Equations and Economic Frictions in the World Economy, Palgrave Handbook of International Trade. Bernhofen, D., Falvey, R., Greenaway, D. and Krieckemeier, U. (eds.). Palgrave-Macmillan Press, forthcoming, 2009.

[5] PORTES, R., REY, H. (2005) The determinants of cross-border equity flows. Journal of International Economics. [online]. 2005, vol. 65 (2), pp. 269-296. Available from: https://doi.org/10.1016/j.jinteco.2004.05.002.

[6] FAGIOLO, G. The international-trade network: gravity equations and topological properties. Journal of Economic Interaction and Coordination. [online]. 2010, vol. 5 (1), pp. 1-25. Available from: https://doi.org/10.1007/s11403$\underline{010-0061-y}$ 
[7] BAIER, S. L., BERGSTRAND, J. H. The growth of world trade: tariffs, transport costs and income similarity. Journal of International Economics. [online]. 2001, vol. 53, pp.1-27. Available from: https://doi.org/10.1016/S00221996(00)00060-X.

[8] BAIER, S. L., BERGSTRAND, J. H. (2009) Bonus vetus OLS: a simple method for approximating international trede-cost effects using the gravity equation. Journal of International Economics. [online]. 2009, vol. 77 (1), pp. 77-85. Available from: https://doi.org/10.1016/j.jinteco.2008.10.004

[9] BAIER, S. L., BERGSTRAND, J. H. Economic determinants of free trade agreements. Journal of International Economics. [online]. 2004, vol. 64 (1), pp. 29-63. Available from: https://doi.org/10.1016/S0022-1996(03)00079-5

[10] BUBÁKOVÁ, P. Gravity Model of International Trade, Its Variables, Assumptions, Problems and Applications. Acta Oeconomica Pragensia, University of Economics. [online]. Prague. 2013, vol. 2013 (2), pp. 3-24. Available from: https://doi.org/10.18267/j.aop.396

[11] ŠEVELA, M. Gravity-type Model of Czech Agricultural Export. Agricultural Economics. [online]. 2002, vol. 48 (10), pp. 463-466. Available from: https://doi.org/10.17221/5353-AGRICECON

[12] SVATOŠ, M., SMUTKA, L. Comparative Advantages of the Czech Agrarian Foreign Trade in Relation to the EU and Third Countries. Acta Universitatis Agriculturae et Silviculturae Mendelianae Brunensis. [online]. 2012. vol. 60 (4), pp. 363-378. Available from: https://doi.org/10.11118/actaun201260040363

[13] TICHÝ, F. Impact of accession to EMU on international trade - case of the Czech Republic. Prague Economic Papers. [online]. 2007, vol. 16 (4), pp. 336-346. Available from: https://doi.org/10.18267/j.pep.312

[14] BENÁČEK, F., PODPIERA, J., PROKOP, L. (2005) Determining Factors of Czech Foreign Trade: A CrossSection Time Series Perspectiv. The Working Paper Series of the Czech National Bank. [online]. 2005. Available from: https://www.cnb.cz/export/sites/cnb/en/economicresearch/.galleries/research publications/cnb wp/cnbwp 2005 03.pdf.

[15] ZEMPLINEROVÁ, A., PANEŠ, P. Competitiveness and state aid to enterprises. Politická ekonomie. [online]. 2008, vol. 56 (2), pp. 182-195. Available from: https://doi.org/10.18267/j.polek.636

[16] ZEMPLINEROVÁ, A. Innovation Activity of Firms and Competition. Politická ekonomie. [online]. 2010. vol. 58 (6), pp.747-760. Available from: https://doi.org/10.18267/i.polek.760

[17] PEPRNÝ, A.,KUBíČKOVÁ, L., ROVNÝ, P. (2010) Method of evaluating the success of the small and mediumsized enterprises. Acta Univ. Agric. Silvic. Mendelianae Brun. [online]. 2010, vol. 58, pp. 183-188. Available from: https://doi.org/10.11118/actaun201058030183

[18] BREITUNG, J., BORN, B. Testing for Serial Correlation in Fixed-Effects Panel Data Models. University of Bonn, 2012.

[19] DE BENEDICTIS, L., TAGLIONI, D. The Gravity Model in International Trade. In TheTrade Impact of European Union Preferential Policies: An Analysis Through Gravity Models. Berlin: Springer, 2011.

[20] HUŠEK, R., PELIKÁN, J. Aplikovaná ekonometrie: Teorie a praxe. Praha: Professional Publishing, 2003. pp. 263. 